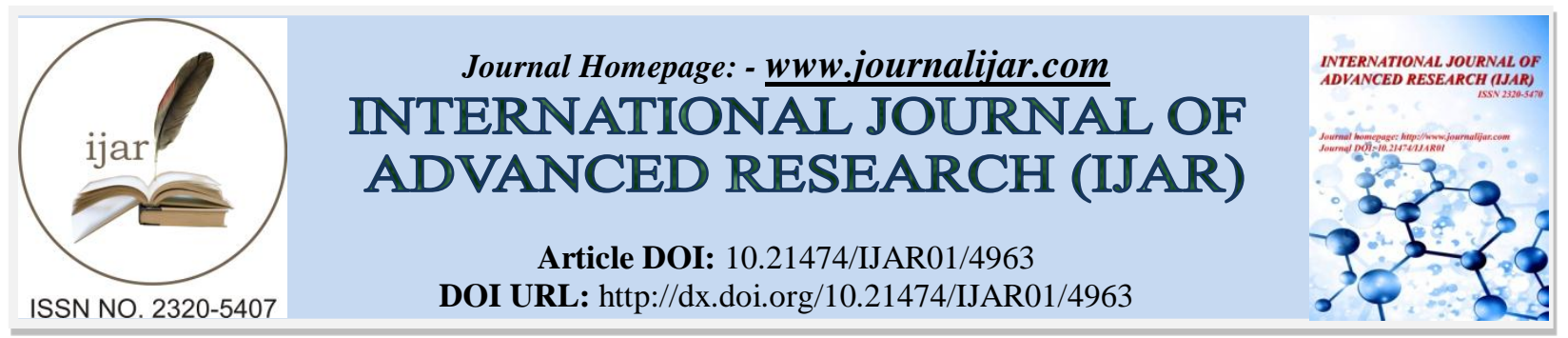

RESEARCH ARTICLE

\title{
HEPATOPROTECTIVE EFFECT OF SELENIUM AND TRICHURIELLA MONSONIAE AGAINST CADMIUM INDUCED LIVER TOXICITY IN RATS.
}

Divya jyothi P, Praneetha P and "Swaroopa Rani V.

Department of Pharmacognosy and Phytochemistry, University College of Pharmaceutical Sciences, Kakatiya University, Warangal-506009, Telangana, India.

\section{Manuscript Info} .......................

\section{Manuscript History}

Received: 26 May 2017

Final Accepted: 28 June 2017

Published: July 2017

Key words:-

Cadmium, Trichuriella monsoniae,

Selenium, anti oxidant, Hepatoprotective activity.

\section{Abstract}

Cadmium $(\mathrm{Cd})$ is one of the most common heavy metal pollutant. It is accumulated particularly in liver and kidney. The aim of this work was to study the protective role of combined Selenium and methanolic extract of whole plant of Trichuriella monsoniae against Cd-induced liver toxicity. Male wister albino rats were divided into 9 groups of 4 each and route of administration selected for the study was oral daily for 21 days. Liver damage was induced by administration of Cadmium $\left(5 \mathrm{mg} / \mathrm{kg} \mathrm{CdCl}{ }_{2}\right)$ and the hepatoprotective activity of the extract and Selenium was assessed on the basis of improvement in the altered levels of various serum biochemical parameters (alanine aminotransferase (ALT), aspartate aminotransferase (AST) alkaline phasphatase (ALP), Gammaglutamyl transferase (GGT), total bilirubin (TB), direct bilirubin (DB), Cholesterol (CHOL), total proteins (TP) and albumin (ALB) and in the changes occurred in the histology of liver of rats taking Silymarin $(100 \mathrm{mg} / \mathrm{kg})$ as standard. Among all the 9 groups tested, the group treated with METM $250 \mathrm{mg} / \mathrm{kg}$ in combination with Selenium was found to be effective. The study revealed that the extract in combination with Selenium has shown better activity then the extract alone against $\mathrm{Cd}$ induced heptotoxicity in rats which may be attributed to the antioxidant activity of Selenium.

Copy Right, IJAR, 2017,. All rights reserved.

\section{Introduction:-}

Cadmium $(\mathrm{Cd})$ is one of the most toxic industrial and environmental pollutants. Cd exists in the earth crust about 0.1 ppm (Hans, 1995). It is of worldwide concern due to its very long half life in humans in addition to its many industrial uses in batteries, electroplasting, plstic, pigments and fertilizers. Human exposure to Cd primarily through the air pollution,smoking and consumption of Cd contaminated food and water (Waisberg et al .,2003). Cigarette smoking is considred to be the most significant source of human Cadmium exposure (Martelli et al., 2006).

Acute exposure to $\mathrm{Cd}$ causes dysuria, polyuria, chest pain, fatigue and headache. Chronic intake of $\mathrm{Cd}$ produces organ dysfunction as a results of cell death, resulting in pulmonary, hepatic and renal tubular diseases. Liver is the most important target organ when considering $\mathrm{Cd}$ induced toxicity because $\mathrm{Cd}$ primarily accumulates in the liver. Lipid peroxidation is considered as the primary mechanism for $\mathrm{Cd}$ induced toxicity through it indirectly involved in the generation of free radicals (Bagchi et al.,1996). Cd exerts its toxic effects through induction of oxidative stress 
by generating reactive oxygen species (ROS) and disturbing the antioxidant defence system(Stohs et al.,2000). Cadmium indirectly induces the generation of free radicals so it is possible to treat the cadmium toxicity by antioxidants .

Selenium (Se) is a essential trace element, component of Selenoproteins and anti oxidant enzymes such as glutathione peroxidase (Gpx) and thiordoxin peroxidase, which protects lipid membrenes and macromolecules in the liver cell intracellular and cellular membranes against oxidative damage generated by reactive oxygen species (ROS) . Selenium shows beneficial effect on Cd induced oxidative stress and hepatotoxicity (Newairy et al., 2007).

Trichuriella monsoniae (L.f.) Bennet of family Amaranthaceae is a perennial herb. It is found all over India. Traditionally, The whole plant of $i$ used in treatment of diabetes, urinary tract infections, wounds, sore throat, diuretic and hepatoprotective. Trichuriella monsoniae has been reported for analgesic, anti inflammatory and anti bacterial activities (Sandhya et al., 2012), antidiabetic activity (Rani et al. 2014) and the methanolic extract of whole plant of Trichuriella monsoniae was reported to contain three known flavonoidal C- glycosides i,e., isoswertisin, 2 $0-\beta$-Dgalactosyl isoswertisin and 2-0- $\beta$-D-xylosyliso swertisin (Chiluka et al., 2016).

To our knowledge,there are no investigations carried out on the protective effect of the combined selenium and methanolic extract of whole plant of Trichuriella monsoniae against $\mathrm{Cd}$ induced hepatotoxicity in rats. The present investigation was aimed to evaluates the protective effect of Selenium and methanolic extract whole plant of Trichuriella monsoniae on Cd induced liver toxicity in rats.

\section{Materials and Methods:-} Collection of plant Material:-

Whole plant of Trichuriella monsoniae was collected in and around Kakatiya University Campus, Warangal, Telangana in the month of November, 2016. The plant material was authenticated by Dr. V.S. Raju (taxonomist), Dept. of Botany, Kakatiya University, Warangal. The voucher specimen (KU/UCPSC/27/2016) of this plant material is being maintained in the herbarium of Department of Pharmacognosy and Phytochemistry,U.C.P.Sc, K.U. warangal for future reference.

\section{Preparation of plant extract:-}

The whole plant was collected, washed in running water, dried under shade and then ground into coarse powder for the maceration process with methanol at room temperature. After exhaustive extraction, the methanolic extract was concentrated under reduced pressure(Rotavapour, Swizaland) to yield brownish green coloured mass. It was coded as METM.

\section{Animals:-}

Male Wistar albino rats weighing 150-200 g were purchased from Sainath agencies, Hyderabad, India with a prior permission from our institutional animal ethical committee( IAEC 32 UCPSC 2016 ) and used for the studies. The animals were housed in standard polypropylene cages, and maintained under standard laboratory conditions (12:12 hour light and dark cycle; at an ambient temperature of $25 \pm 50 \mathrm{C}$; $35-60 \%$ of relative humidity). The animals were fed with standard rat pellet diet and water ad libutum.

\section{Chemicals:-}

Cadmium $\left(\mathrm{Cdcl}_{2}\right)$ and Selenium $\left(\mathrm{Na}_{2} \mathrm{SeO}_{4}\right)$ were purchased from Himedia, Mumbai., India. Silymarin was obtained from Sigma Aldrich, China. The biochemical analytical kits Aspartate aminotransferase (AST), Alanine aminotransferase (ALT), Alkaline phosphatase (ALP), Total Bilirubin (TB), Cholesterol (CHOL), Direct Bilirubin (DB), Albumin (ALB), and Total Protein(TP) were purchased from Merck Specialties Private Limited, Mumbai, India. All other chemicals and solvents used were of analytical grade.

\section{Acute Toxicity Study:-}

Acute toxicity study was carried out for the methanolic extract of Trichuriella monsoniae according too the Organization for Economic Cooperation and Development (OECD) 420 guidelines (OECD 2001). All animals were observed for toxic symptoms and mortality for 72 hour. 


\section{Experimental Design:-}

The experiment was performed according to the method given in the literature with minor modifications (Rajasekaran and Periaswamy, 2012). One week after acclimatizations, rats were randomly divided into nine groups of 4 each.The route of administration of study was oral daily for 21 days.Group- 1 served as normal control received $2 \%$ gum acacia $(1 \mathrm{ml} / \mathrm{kg})$ while Group2-9 were given Cadmium $\left(5 \mathrm{mg} / \mathrm{kg} \mathrm{Cd}\right.$ as $\left.\mathrm{CdCl}_{2}\right)$ by dissolved in the drinking water for 21 days to induce hepatotoxicity. Group-2 served as the positive control (Cadmium only), Group-3 (standard) treated with Silymarin $\left(100 \mathrm{mg} / \mathrm{kg}\right.$ ) and Selenium $\left(1 \mathrm{mg} / \mathrm{kg}\right.$ as $\left.\mathrm{Na}_{2} \mathrm{SeO}_{4}\right)$, Group-4 treated with Silymarin $(100 \mathrm{mg} / \mathrm{kg})$ only, Group-5 treated with Selenium $(1 \mathrm{mg} / \mathrm{kg}$ ) only, Group-6 treated with METM at the doses of 250 $\mathrm{mg} / \mathrm{kg}$ bw, Group-7 treated with only METM $500 \mathrm{mg} / \mathrm{kg}$ bw, Group-8 treated with Selenium and METM 250, Group-9 treated with Selenium and METM $500 \mathrm{mg} / \mathrm{kg}$ bw, At the end of the experiment all rats were sacrificed, blood and liver tissue samples were taken for the estimation of serum biochemical parameters and histological studies respectively.

\section{Blood Samplings:-}

The blood was collected from the retro orbital plexus of the rats of all groups under ether anesthesia. The blood samples were allowed to stand for $30 \mathrm{~min}$ at room temperature and then centrifuged (Remi, model: R8-C, India) at $3000 \mathrm{rpm}$ for $30 \mathrm{~min}$ to separate the serum. The serum was analyzed for various biochemical parameters such as alanine aminotransferase (ALT), aspartate aminotransferase (AST) alkaline phasphatase (ALP), Gamma-glutamyl transferase (GGT), total bilirubin (TB), direct bilirubin (DB), Cholesterol (CHOL), total proteins (TP) and albumin (ALB).

\section{Histological Studies:-}

The animals were then dissected and the livers were carefully removed and washed with $0.9 \%$ saline solution. The liver tissue was kept in $10 \%$ formalin and embedded in paraffin wax. $5 \mu \mathrm{m}$ slices were stained with hematoxylin and eosin (H\&E), and photographs were taken.

\section{Statistical Analysis:-}

All the values were expressed as Mean \pm SD. The data was statistically evaluated using one way analysis of variance (ANOVA) followed by Dunnetts test,all vs control, using Graph pad Prism 3 computer software. P value of 0.05 or less was considered to be significant.

\section{Results:-}

Acute toxicity study:-

The extract METM did not cause any adverse effects and mortality up to a dose level of $2000 \mathrm{mg} / \mathrm{kg}$ b.w.p.o. and were considered as safe. Hence, two doses 250 and $500 \mathrm{mg} / \mathrm{kg}$ b.w.of METM were selected for the study.

Effect of Selenium \& METM on serum biochemical parameters Cadmium induced hepatotoxicity in rats:Oral administration of Cadmium caused a significant liver injury manifested by elevation in serum biochemical parameters AST, ALT, ALP, GGT,CHOL, TB, DB, cholesterol $(\mathrm{p}<0.01)$ and decrease in TP and ALB in serum as compared to the the control groupThe rats treated with METM 250 and $500 \mathrm{mg} / \mathrm{kg}$, standard Silymarin $(100 \mathrm{mg} / \mathrm{kg})$, METM and Selenium at $250 \mathrm{mg} / \mathrm{kg}$ and $500 \mathrm{mg} / \mathrm{kg}$ and Selenium $(1 \mathrm{mg} / \mathrm{kg}$ ) has shown significant reversal of serum biochemical parameters. Among all the groups tested,the combination of METM $250 \mathrm{mg} / \mathrm{kg}$ with Seleniu was found to be effective. The results were presented in table 1 .

\section{Effect On Histology Of Rats:-}

Normal liver architecture was seen in control group, while in cadmium treated rats, dilatation in sinusoidal spaces, degeneration and deformation of hepatocytes, centrilobular necrosis, and inflammatory infiltration of hepatocytes were seen (Fig.1.B ).However, treatment wth all the test dose and also test doses in combination with Selenium has shown remarkable protection against $\mathrm{Cd}$ induced histological alterations. Among all the groups tested, METM at $250 \mathrm{mg} / \mathrm{kg}$ with selenium has shown better protection substantiating the hepatoprotective activity.

Thus the histopathological studies support the findings of serum biochemical parameters of the study, revealing the hepatoprotective activity of the extract (METM) and Selenium against Cadmium intoxication in rats. 


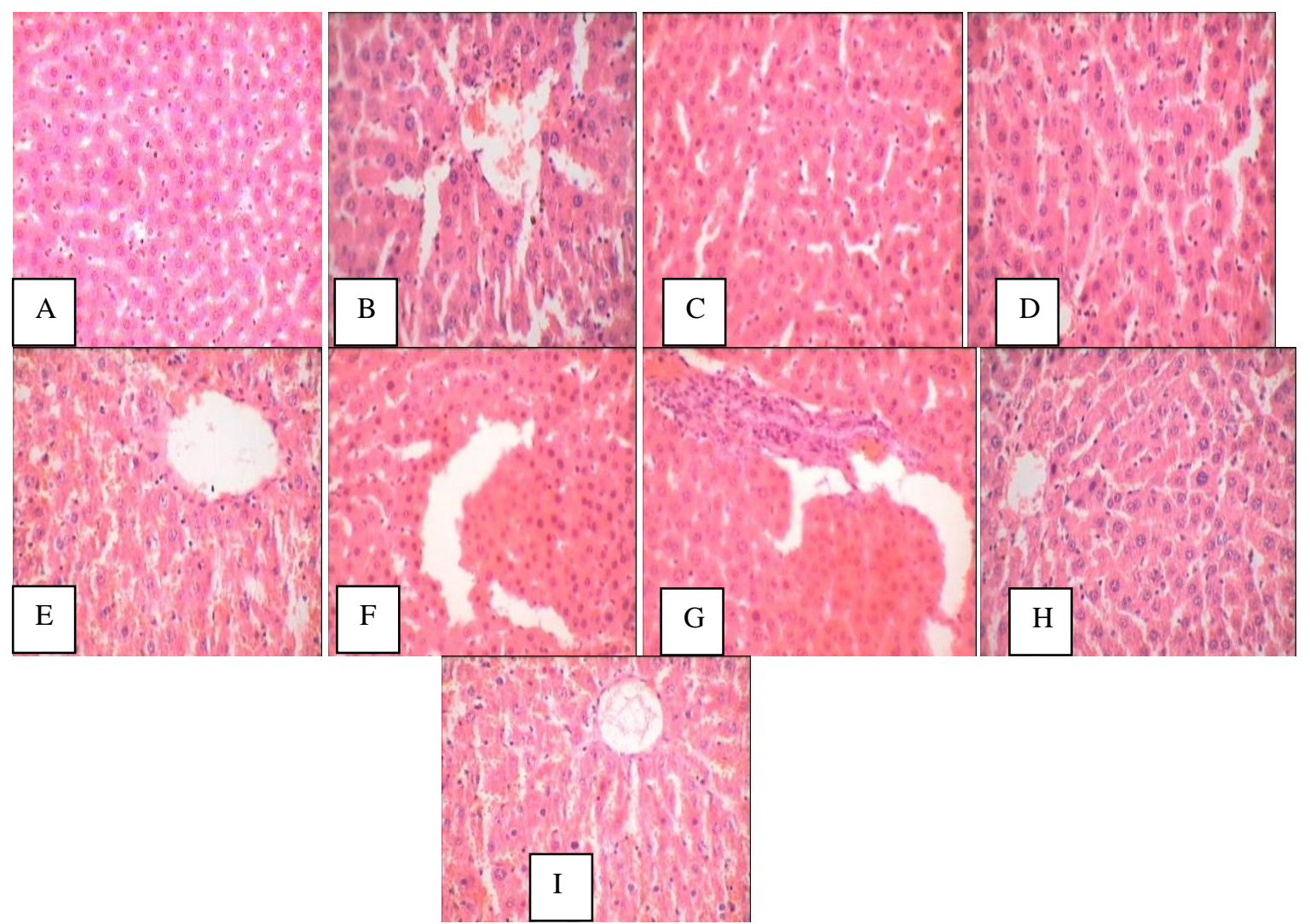

Fig.1:- Photomicrographs of liver sections .A .Control group. B. Toxic group treated with Cd. C.Standard group treated with Se and silymarin. D. Treated with silymarin only. E. Trated with Se only. F.Treated with METM $250 \mathrm{mg} / \mathrm{kg}$ G.Treated with METM $500 \mathrm{mg} / \mathrm{kg}$. H.Treated with combination of Se and METM $250 \mathrm{mg} / \mathrm{kg}$. I. Treated with combination of Se and METM 500mg/kg. 
Table 1:- Effect Of Hepatoprotective Effect Pf Metm \& Selenium On Different Parameters In Cadmium Induced Liver Damage In Rats

\begin{tabular}{|c|c|c|c|c|c|c|c|c|c|}
\hline Groups & $\begin{array}{c}\text { ALT } \\
\text { (IU/L) }\end{array}$ & $\begin{array}{c}\text { AST } \\
\text { (IU/L) }\end{array}$ & $\begin{array}{c}\text { ALP } \\
\text { (IIU/L) }\end{array}$ & $\begin{array}{l}\text { CHOL } \\
(\mathrm{mg} / \mathrm{dl})\end{array}$ & $\begin{array}{c}\mathrm{TB} \\
(\mathrm{mg} / \mathrm{dl})\end{array}$ & $\begin{array}{c}\mathrm{DB} \\
(\mathrm{mg} / \mathrm{dl})\end{array}$ & $\begin{array}{l}\text { GGT } \\
\text { (IU/L) }\end{array}$ & $\begin{array}{c}\text { ALBUMI } \\
\mathrm{N} \\
(\mathrm{g} / \mathrm{dl})\end{array}$ & $\begin{array}{c}\mathrm{TP} \\
(\mathrm{g} / \mathrm{dl})\end{array}$ \\
\hline Normal & $\begin{array}{c}46.517 \pm 3 \\
.974\end{array}$ & $\begin{array}{c}65.467 \pm 3 \\
.974\end{array}$ & $\begin{array}{c}455.12 \pm \\
26.16\end{array}$ & $\begin{array}{l}2.05 \pm 6 \\
.8\end{array}$ & $\begin{array}{l}0.0600 \\
\pm 0.008\end{array}$ & $\begin{array}{l}0.0216 \\
\pm 0.007\end{array}$ & $\begin{array}{c}.567 \pm 0 . \\
233\end{array}$ & $\begin{array}{c}4.59 \pm 0.0 \\
87\end{array}$ & $\begin{array}{c}8.517 \pm \\
0.17\end{array}$ \\
\hline $\begin{array}{l}\text { Toxic(Cadm } \\
\text { ium) }\end{array}$ & $\begin{array}{c}186.8 \pm 3 \\
9 * *\end{array}$ & $\begin{array}{c}226.02 \pm 4 \\
.510 * *\end{array}$ & $\begin{array}{c}1227.9 \pm \\
5.17 * *\end{array}$ & $\begin{array}{c}95.53 \pm 8 \\
.1 * *\end{array}$ & $\begin{array}{l}2.90 \pm 0 . \\
209 * *\end{array}$ & $\begin{array}{c}2.1 \pm 0.1 \\
87 * *\end{array}$ & $\begin{array}{l}46.900 \pm 1 \\
.88 * *\end{array}$ & $\begin{array}{c}2.53 \pm 0.2 \\
3 * *\end{array}$ & $\begin{array}{l}5.233 \pm \\
0.17 * *\end{array}$ \\
\hline $\begin{array}{c}\text { Standard }+ \text { Se } \\
\text { lenim }+\mathrm{Cd}\end{array}$ & $\begin{array}{c}74.7 \pm 3.3 \\
3 * * \\
(80.07 \%)\end{array}$ & $\begin{array}{c}76.117 \pm 2 \\
.666 * * \\
(93.36 \%)\end{array}$ & $\begin{array}{l}556.82 \pm \\
27.24 * * \\
(86.8 \%)\end{array}$ & $\begin{array}{c}52.42 \pm 1 \\
.3 * * \\
(80 \%)\end{array}$ & $\begin{array}{l}0.51 \pm 0 . \\
04 \mathrm{O}^{* *} \\
(84 \%)\end{array}$ & $\begin{array}{c}0.27 \pm 0 . \\
018^{* *} \\
(88 \%)\end{array}$ & $\begin{array}{c}12.33 \pm 0 . \\
507 * * \\
(83 \%)\end{array}$ & $\begin{array}{c}4.183 \pm 0 . \\
085 * * \\
(80 \%)\end{array}$ & $\begin{array}{l}8.033 \pm \\
0.19 * * \\
(85 \%)\end{array}$ \\
\hline Stanc & $\begin{array}{c}80.1 \pm 7.0 \\
54 * * \\
(76.09 \%) \\
\end{array}$ & $\begin{array}{c}80.950 \pm 3 \\
.321 * * \\
(90 \%) \\
\end{array}$ & $\begin{array}{c}589.0 \pm 1 \\
5.52 * * \\
(82.6 \%) \\
\end{array}$ & $\begin{array}{c}58.16 \pm 2 \\
.4 * * \\
(69 \%) \\
\end{array}$ & $\begin{array}{c}0.58 \pm 0 . \\
024 * * \\
(81 \%)\end{array}$ & $\begin{array}{c}0.29 \pm 0 . \\
023 * * \\
(87 \%)\end{array}$ & $\begin{array}{c}13.417 \pm 0 \\
.231 * * \\
(81 \%) \\
\end{array}$ & $\begin{array}{c}3.98 \pm 0.0 \\
89 * * \\
(70 \%) \\
\end{array}$ & $\begin{array}{l}7.667 \pm \\
0.12 * * \\
(75 \%) \\
\end{array}$ \\
\hline $\begin{array}{c}\text { Selenium+C } \\
\mathrm{d}\end{array}$ & $\begin{array}{c}95.6 \pm 5.6 \\
6 * * \\
(65.1 \%)\end{array}$ & $\begin{array}{c}92.83 \pm 1 \\
821 * * \\
(82.9 \%)\end{array}$ & $\begin{array}{c}568.63 \pm \\
22.90 * * \\
(69 \%)\end{array}$ & $\begin{array}{c}78.35 \pm 2 \\
.6 * * \\
(32.1 \%)\end{array}$ & $\begin{array}{c}0.89 \pm 0 . \\
034 * * \\
(70 \%)\end{array}$ & $\begin{array}{c}0.41 \pm 0 . \\
016^{* *} \\
(81 \%)\end{array}$ & $\begin{array}{c}16.6 \pm 0.1 \\
16 * * \\
(73 \%)\end{array}$ & $\begin{array}{c}3.382 \pm 0 . \\
072 * * \\
(58 \%)\end{array}$ & $\begin{array}{c}6.76 \pm 0 . \\
24 * * \\
(46 \%)\end{array}$ \\
\hline $\begin{array}{c}\mathrm{Cd}+250 \mathrm{ME} \\
\mathrm{TM}\end{array}$ & $\begin{array}{c}100.33 \pm 3 \\
.143 * * \\
(61.6 \%)\end{array}$ & $\begin{array}{c}98.556 \pm 2 \\
.94 * * \\
(79.3 \%)\end{array}$ & $\begin{array}{l}736.72 \pm \\
41.01 * * \\
(63.5 \%)\end{array}$ & $\begin{array}{c}79.16 \pm 8 \\
.6 * * \\
(30.6 \%)\end{array}$ & $\begin{array}{c}0.92 \pm 0 . \\
251 * * \\
(69 \%)\end{array}$ & $\begin{array}{c}0.43 \pm 0 . \\
012 * * \\
(80 \%)\end{array}$ & $\begin{array}{c}16.95 \pm 0 . \\
187 * * \\
(72 \%)\end{array}$ & $\begin{array}{c}3.223 \pm 0 . \\
096 * * \\
(33 \%)\end{array}$ & $\begin{array}{c}6.43 \pm 0 . \\
27 * * \\
(36 \%)\end{array}$ \\
\hline $\begin{array}{c}\mathrm{Cd}+500 \mathrm{ME} \\
\mathrm{TM}\end{array}$ & $\begin{array}{c}110.35 \pm 4 \\
.456 * * \\
(54.5 \%)\end{array}$ & $\begin{array}{c}104.42 \pm 8 \\
.533 * * \\
(75.7 \%)\end{array}$ & $\begin{array}{l}833.83 \pm \\
24.31 * * \\
(50.9 \%)\end{array}$ & $\begin{array}{c}82.31 \pm 8 \\
.6 * * \\
(24.7 \%)\end{array}$ & $\begin{array}{l}1.23 \pm 0 . \\
234 * * \\
(58 \%)\end{array}$ & $\begin{array}{c}0.48 \pm 0 . \\
02 * * \\
(77 \%)\end{array}$ & $\begin{array}{c}17.400 \pm 0 \\
.141 * * \\
(71 \%)\end{array}$ & $\begin{array}{c}3.132 \pm 0 . \\
083 * * \\
(29 \%)\end{array}$ & $\begin{array}{l}6.233 \pm \\
0.10 * * \\
(30 \%)\end{array}$ \\
\hline $\begin{array}{c}\mathrm{Cd}+\mathrm{se}+250 \\
\text { METM }\end{array}$ & $\begin{array}{c}83.886 \pm 3 \\
.023 * * \\
(73.3 \%) \\
\end{array}$ & $\begin{array}{c}82.650 \pm 3 \\
.011^{* *} \\
(89.4 \%) \\
\end{array}$ & $\begin{array}{c}620 \pm 26 . \\
00 * * \\
(78.6 \%)\end{array}$ & $\begin{array}{c}62.31 \pm 1 \\
.1 * * \\
(61 \%) \\
\end{array}$ & $\begin{array}{c}0.68 \pm 0 . \\
014 * * \\
(78 \%)\end{array}$ & $\begin{array}{c}0.33 \pm 0 . \\
018^{* *} \\
(85 \%)\end{array}$ & $\begin{array}{c}14.533 \pm 0 \\
.163 * * \\
(78 \%) \\
\end{array}$ & $\begin{array}{c}3.887 \pm 0 . \\
2753 * * \\
(65 \%)\end{array}$ & $\begin{array}{l}7.485 \pm \\
0.11 * * \\
(68 \%)\end{array}$ \\
\hline $\begin{array}{c}\mathrm{Cd}+\mathrm{se}+500 \\
\text { METM }\end{array}$ & $\begin{array}{c}90.10 \pm 2 . \\
836 * * \\
(68.97 \%)\end{array}$ & $\begin{array}{c}88.57 \pm 9 . \\
001 * * \\
(85.66 \%)\end{array}$ & $\begin{array}{l}747.62 \pm \\
29.01 * * \\
(71.2 \%)\end{array}$ & $\begin{array}{c}72.36 \pm 1 \\
.5 * * \\
(43.3 \%)\end{array}$ & $\begin{array}{l}0.72 \pm 0 . \\
231 * * \\
(76 \%)\end{array}$ & $\begin{array}{c}0.38 \pm 0 . \\
014 * * \\
(82 \%)\end{array}$ & $\begin{array}{c}15.36 \pm 0 . \\
160 * * \\
(76.2 \%)\end{array}$ & $\begin{array}{c}3.532 \pm 0 . \\
833 * * \\
(63 \%)\end{array}$ & $\begin{array}{c}7.31 \pm 0 . \\
17 * * \\
(63 \%)\end{array}$ \\
\hline
\end{tabular}

$\mathrm{N}=6$, Data expressed as mean $\pm \mathrm{SD}$, values in parathesis indicate percentage recovery

$\mathrm{P}$ value- control Vs other groups, ${ }^{* *} \mathrm{P}<0.01, * \mathrm{P}<0.05$

\section{Discussion:-}

Cadmium is a toxic metal that is widely used in different industries. liver is the primary organ for the cd toxicity.It promotes an early oxidative stress and leads to the development of serious pathological conditions because of its long retention in some tissues ( Bagchi et al., 2000).

In the present study, $C d$ induced hepatic dysfunction was evidenced by an increased serum Hepatic marker enzymes (AST, ALT, ALP), Cholesterol, Total bilirubin ,Direct bilirubin, GGT and decreased levels of Albumin and Total protein. The purpose of the present investigation was to evaluate the potential protective effect of methanolic extract of whole plant of Trichuriella monsoniae in combination with Selenium on Cd induced hepatotoxicity compared to methanolic extract of whole plant of Trichuriella monsoniae or Selenium treatment alone in rats.

Flavonoids are one of the most numerous and widespread group of naturally occurring antioxidants and as potent inhibitors of lipid peroxidation in a biological membrane. They usually contain one or more aromatic hydroxyl groups in their moiety which is responsible for the antioxidant activity of flavonoids (Van Acker et al., 2000) which play vital role in the treatment of liver damage.

Phytochemical investigation of methanolic extract of Trichuriella monsoniae was revealed that it contain three known flavonoidal C- glycosides i,e., isoswertisin, 2-0- $\beta$-Dgalactosyl isoswertisin and 2-0- $\beta$-D-xylosyliso swertisin (Chiluka et al., 2016). 
Selenium ( $\mathrm{Se}$ ) is an essential nutritional trace element for both humans and animals, plays an important role in antioxidant defence systems, and protects the structure and functions of proteins, DNA, and chromosomes against oxidation injury (Yuan and Tang, 1999).

In this context the present study confirmed that the co-administration of Selenium ( $1 \mathrm{mg} / \mathrm{kg})$ and METM at the dose of $250 \mathrm{mg} / \mathrm{kg}$ significantly preserved the hepatic activities against the toxic effects exerted by Cadmium may be its antioxidant property.

ALT and AST are hepato enzymes. These enzymes are indicators of cellular damage. The increased levels of these enzymes are seen in serum after the $\mathrm{Cd}$ treatment, it causes structural and functional destruction to the cell membrane and increased membrane permeability resulting in leakage of hepatic enzymes into the blood stream. ALP and GGT are cholestatic enzymes. These enzymes are indicators of cholestatic damage. ALP is an enzyme present in the cell lining of bile ducts of the liver. The ALP levels in serum rises with large bile duct obstruction, intra hepatic cholestasis, or infiltrative diseases of the liver. GGT is more sensitive marker of cholestatic damage, the increased levels of GGT levels along with ALP levels in serum is an indicator of hepatic dysfunction.

The increased TB, DB levels in serum is a clear marker of hepatic dysfunction due to Obstructions in bile ducts. Albumin and total Protein are the indicators for synthetic capacity of liver. The decreased levels of ALB and TP in serum is due is deceased synthetic capacity of the liver.

These results also supported by the histopathological assessment of liver which revealed by remarkable changes in the normal liver architecture of rats showing dilatation in sinusoidal spaces, degeneration and deformation of hepatocytes, centrilobular necrosis, and inflammatory infiltration of hepatocytes. All the test groups showed significant reduction in the elevated level of the serum AST, ALT, ALP,GGT, TBL, DBL, CHOL and enhances the decreased levels ALB and TP, in addition to improvement of the histopathological changes in Cadmium induced toxicity.Among all the groups combined treatment of Selenium and METM at the low dose $(250 \mathrm{mg} / \mathrm{kg}) \mathrm{showed}$ significant effect on Cd induced liver toxicity.

\section{Conclusion:-}

The results of the present study demonstrated that treatment of combined Selenium and methanolic extract of whole plant of Trichuriella monsoniae inhibits the liver toxicity in Cd intoxicated rats.

It was concluded that methanolic extract of whole plant of Trichuriella monsoniae in combination with Selenium showen significant effect than the extract alone. Combination of methanolic extract of whole plant of Trichuriella monsoniae and Selenium had a synergistic hepatoprotective effect against Cadmium induced liver toxicity.

\section{References:-}

1. Bagchi, D.M. Bagchi, E.A. Hassoun and Stohs,S.J.(1996): Cadmium induced excreation of urinary lipid metabolites,DNA damage, glutathione depletion and hepatic lipid peroxidation in SpragueDawley rats.Biol. Trace Elements Res., 52: 521-529.

2. Bagchi, D. Bagchi, M. Stohs, S.J. Ray, .S.D. Kuszynki,C.A. Pruess, H.G.(2000). Free radical and grape seed proanthocyanidin extract: importance in human health and disease prevention.Toxicology., 148: 187-97.

3. Hans Wedepohl,K. (1995).The composition of the continental crust.Geochimica et Cosmochimica Acta.,59(7):1217-1232

4. Martelli, A. Rousseelet, C. Dycke,A. Bouron,J. Moulis, M.(2006).Cadmium toxicity in animal cell by interference with essential metals.Biochemie.,88:1807-1814.

5. Newairy, A.A. El-Sharaky, A.S. Badreldeen, M.M. Eweda, S.M. Sheweita, S.A. ( 2007): The hepatoprotective effects of selenium against cadmium toxicity in rats. Toxicology., 242 (1-3): 23-30.

6. OECD guidelines for testing of chemicals. Test No: 420: Acute oral toxicity, $17^{\text {th }}$ dec, 2001.

7. Rajasekaran,A. and M. Periasamy.,2012. Hepatoprotective effect of ethanolic leaf extract of Calycopteris floribunda Lam on Cadmium induced hepatotoxicity in rats. Res j pharma bio chem sci., 3(3), 382-390.

8. Sandhya, S. Sai, KP. Vinod, KR. Banji, D. Kumar, K. Rajeshwar, T.( 2012): In ova angiogenesis analgesic and anti-inflammatory potency of Aerva monsoniae (Amaranthaceae). Asian Pac J Trop Dis ., 2: 385-389. 
9. Stohs, SJ. Bagachi, D. Hassoun, E. Baguchi, M.( 2000): Oxidative mechanisms in the toxicity of chromium and cadmium ions. J Environ Pathol Toxicol Oncol., 20: 77-88.

10. Swaroopa rani, V. Praneetha, P. Krishna Mohan, G. Ravi kumar, B.( 2001): Antihyperglycemic activity of Trichuriella monsoniae Bennet in streptozotocin induced diabetic rats. Inter J Pharma Educ and Res., 4(4).

11. Van Acker, FAA. Schouten, O. Haenen, GR. Van Dervijgh, WJF . Bast, A. (2000): Flavonoids can replace $\alpha-$ tocopherol as an antioxidant. FEBS Lett ., 473:145-8.

12. Waisberge, M. Joseph, P. Hale, B. Beyersmann, D. (2003): Molecular mechanisms of cadmium carcinogenesis. Toxocology ., 192: 95-11.

13. Yuan, X. and Tang. (1999): Lead effect on DNA and albumin in chicken of Selenium nutrition. J Environ Sci Health A., 34(9): 1875-1887. 